\title{
Soil carbon stock in silvopastoral system, pasture and sugarcaneculture
}

\author{
Reserva de carbono en el suelo de sistemas silvopastoriles, pastizales \\ y de plantación de caña de azúcar
}

\author{
Paulo R. Da Rocha Junior ${ }^{1 *}$, Mariana Lopes Soares², Iolanda Gonçalves Ribeiro², \\ Alexandre Sylvio Vieira Da Costa ${ }^{1}$, Guilherme Kangussú Donagemma ${ }^{3}$, Eduardo De Sá Mendonça ${ }^{1}$
}

\begin{abstract}
The conversion of natural system in tillage agriculture areas is largely responsible for the reduction of Organic Carbon stock $(O C$ stock) in the soil and increases $\mathrm{C}-\mathrm{CO}_{2}$ atmospheric release in tropical countries. The objective of this study was to evaluate the impacts of different situations of soil uses (silvopastoral, pasture and sugarcane) in $O C$-stocks of Utilsols in the regions of Vale do Rio Doce in the state of Minas Gerais. It was determined contents of total soil organic carbon (SOC) and soil bulk density (Bd) in different situations studied. The use of anthropic soil is promoting the increase of the soil $B d$ due to the deployment of cultures being preformed mechanically, therefore the systems provided higher content of SOC and consequently increased the $O C$-stock. The highest content of $S O C$ was found in the area with sugarcane. The studied situations provided increase in the $O C$-stock in depth 0-10 $\mathrm{cm}$, of 5,397 $\mathrm{Mg} \mathrm{ha}^{-1}, 3,494 \mathrm{Mg} \mathrm{ha}^{-1}$ and 1,964 $\mathrm{Mg} \mathrm{ha}^{-1}$ for sugarcane, silvopastoral system and pasture. The management of fertilization and harvesting of sugarcane in the region of the city Governador Valadares is efficient in increasing the $O C$-stock, including being greater than the secondaryforest, and the silvopastoral site shows a greater potential in carbon stocking in the surface layers $(0-10 \mathrm{~cm}$ and $10-20 \mathrm{~cm})$ compared to continuous grazing areas.
\end{abstract}

Key words: conversion system, organic residue inputs, soilcarbon.

\section{RESUMEN}

La conversión de sistemas naturales en tierras agrícolas es uno de los principales factores responsables por la reducción de la reserva de Cen el suelo y el aumento de la liberación de $\mathrm{C}-\mathrm{CO}_{2}$ atmosférico en los países de clima tropical. El objetivo del presente estudio fue evaluar el impacto de los diferentes usos del suelo (silvopastoril, pastizales y plantación de caña de azúcar) en las reservas de C de un suelo arcilloso rojo-amarillo ubicado en la región del Valle del Río Doce, Minas Gerais. Para este fin fueron determinados los contenidos de carbono orgánico total (SOC) y la densidad del suelo (Bd) en los distintos sistemas estudiados. El uso antrópico del suelo está favoreciendo el aumento de la Bd en función de la mecanización del suelo. Sin embargo, los sistemas proporcionaron niveles de SOC elevados al suelo y consecuentemente se incrementaron las reservas de C. En el área con caña de azúcar se encontraron los niveles más elevados de SOC. En las áreas estudiadas se observó un incremento de los estoques de C entre la profundidad de 0-10 cm, de $5397 \mathrm{Mg} \mathrm{ha}^{-1}, 3494 \mathrm{Mg} \mathrm{ha}^{-1}$ y $1964 \mathrm{Mg} \mathrm{ha}^{-1}$ para las áreas con caña de azúcar, sistema silvopastoril y pastizal, respectivamente. El manejo de la fertilización y de la cosecha de caña de azúcar en la región de Gobernador Valadares es eficiente en el incremento de las reservas de C en el suelo, siendo incluso superior que las reservas encontradas en el fragmento florestal, y el área silvopastoril presenta mayor potencial para el almacenamiento de C en los estratos superficiales (0-10 cm y 10-20 cm) comparado con las áreas de pastoreo continuo.

Palabras clave: conversión de sistemas, aporte de residuos orgánicos, carbono orgánico total.

1 Department of Plant Production, Federal University of Espírito Santo - UFES, zip code 29500-000, Alto Universitário, Guararema, Alegre - ES, Brazil, Post office box 16.

2 Department of Agronomy, University Vale of Rio Doce - UNIVALE, zip code 35032-180, Street Israel Pinheiro 2000, Universitário, Governador Valadares - MG,Post office box 295.

3 EMBRAPA-CNPS, zip code 24460-000, Jardim Botânico, Rio de Janeiro - RJ, Brazil.

* Corresponding author: asylvio@unvale.br

Fecha de Recepción: 19 Agosto, 2012.

Fecha de Aceptación: 21 Noviembre, 2013. 


\section{Introduction}

The conversion of natural system in tillage agriculture areas is largely responsible for the reduction of organic carbon stock (OC-stock) in the soil and increases $\mathrm{C}-\mathrm{CO}_{2}$ atmospheric release in tropical countries (Neves et al., 2004). The function of the soil as a source or greenhouse gases sink depends on the management system in which they are submitted (IPCC, 2001).

Management systems that favor the larger input of organic residue to the soil are important alternative to increase the sink capacity of $\mathrm{C}-\mathrm{CO}_{2}$ atmospheric and global warming mitigation (Macedo et al., 2008). These systems can contribute mainly to the areas that suffer conversion in an exploratory form and currently are degraded. A great part of these areas can be related to areas used for animal feed as pasture and/or sugarcane field.

In Brazil it is estimated that $80 \%$ of the agriculture regions economically important in the Amazon and Cerrado are found in some degradation stage or degraded (Dias-Filho, 2010). In the region Vale do Rio Doce in Minas Gerais the scenario repeats itself especially in Governador Valadares which if one of the most degraded region of the state.

There is increasing interest in indentifying the managements systems of cultures and pastures that promote the improvement of $O C$-stock in the soil. Having sugarcane management as a reference, this was previously done with burning to facilitate the culture management and harvest. Due to environmental concerns, in the last two decades the sugarcane production system uses cane vinasse to fertilize the plantation and mechanized harvest. Another important aspect is the adoption of integrated livestock farm forest system, agroforestry system and silvopastoral system. Silvopastoral system is appointed to be an important potential to recover the $O C$-stock lost in the soil (Neves et al., 2004).

The decrease of $\mathrm{C}-\mathrm{CO}_{2}$ emission and the increase of soil organic carbon stock results in improving the soil quality, increasing productivity, contributing to the sustainability of agroecosystem and the mitigation of global warming (Silva \& Mendonça, 2007). Thus, the objective of this study was to evaluate the impacts of different situations studied (silvopastoral, pasture and sugarcane) in $O C$-stock of Utilsol in the regions of Vale do Rio Doce in the state of Minas Gerais.

\section{Materials and Methods}

The study was held in the University Vale do Rio Doce (UNIVALE)'s experimental field on Campus II, located in Governador Valadares in the state of Minas Gerais. The experimental field is bounded by geographical coordinates, $18^{\circ} 51^{\prime} \mathrm{S}$ latitude and 41 $56^{\prime}$ ' W longitude, and altitude: $148 \mathrm{~m}$ (Figure 1). The climate in the region is tropical sub-hot and sub-dry, according to Koppen's classification. The average annual temperature is $25^{\circ} \mathrm{C}$ (June) to $27^{\circ} \mathrm{C}$ (February), the average rainfall is $1,114 \mathrm{~mm}$ per year from November to March. The description of the physical and chemical characteristics of soil are found in Tables 1 and 2 and all collecting sites are located on a plain relief, being that the soil of these sites are classified as Utisol.

The management systems evaluate was: sugarcane (SC), silvopastoral (SP), pasture (PT) and secondaryforest (SF) used as a reference site. All sites were deforest over 70 years and were submitted to sugarcane plantations for 30 years with no history of manure or liming before the establishment of the experiment.

The managed site with sugarcane (SC) crop was established 5 years ago having as a prior use a sugarcane cultivation. The current sugarcane plantation was held in a furrow after plowing and harrowing of the total area, the spacing used was $2.0 \times 0.80 \mathrm{~m}$ with liming, mineral fertilizer (N-P-K) and organic fertilizer at planting. In the following years the implantation of the sugarcane fertilization (N-P-K) was carried out to a yield above 80 ton per ha ${ }^{-1}$ as described by Alvarez V. et al. (1999). This site is irrigated since its implantation and harvesting of sugarcane and performed manually leaving soil mulching.

The site occupied with silvopastoral system (SP) was implanted 11 years ago with intercropping of coconut and Brachiaria brizantha pasture and the previous use with conventional corn plantations. The coconut implantation was held in holes with a spacing of $6.0 \times 6.0 \mathrm{~m}$ performing liming and fertilizer N-P-K at planting and cover according to the nutritional demand (Alvarez V. et al., 1999). Before the pasture implantation was performed bean planting, the silvopastoral site (coconut/pasture) is irrigated and the animals intensively graze being divided into plots.

The managed site with pasture (PT) was implanted 6 years ago and the current pasture 


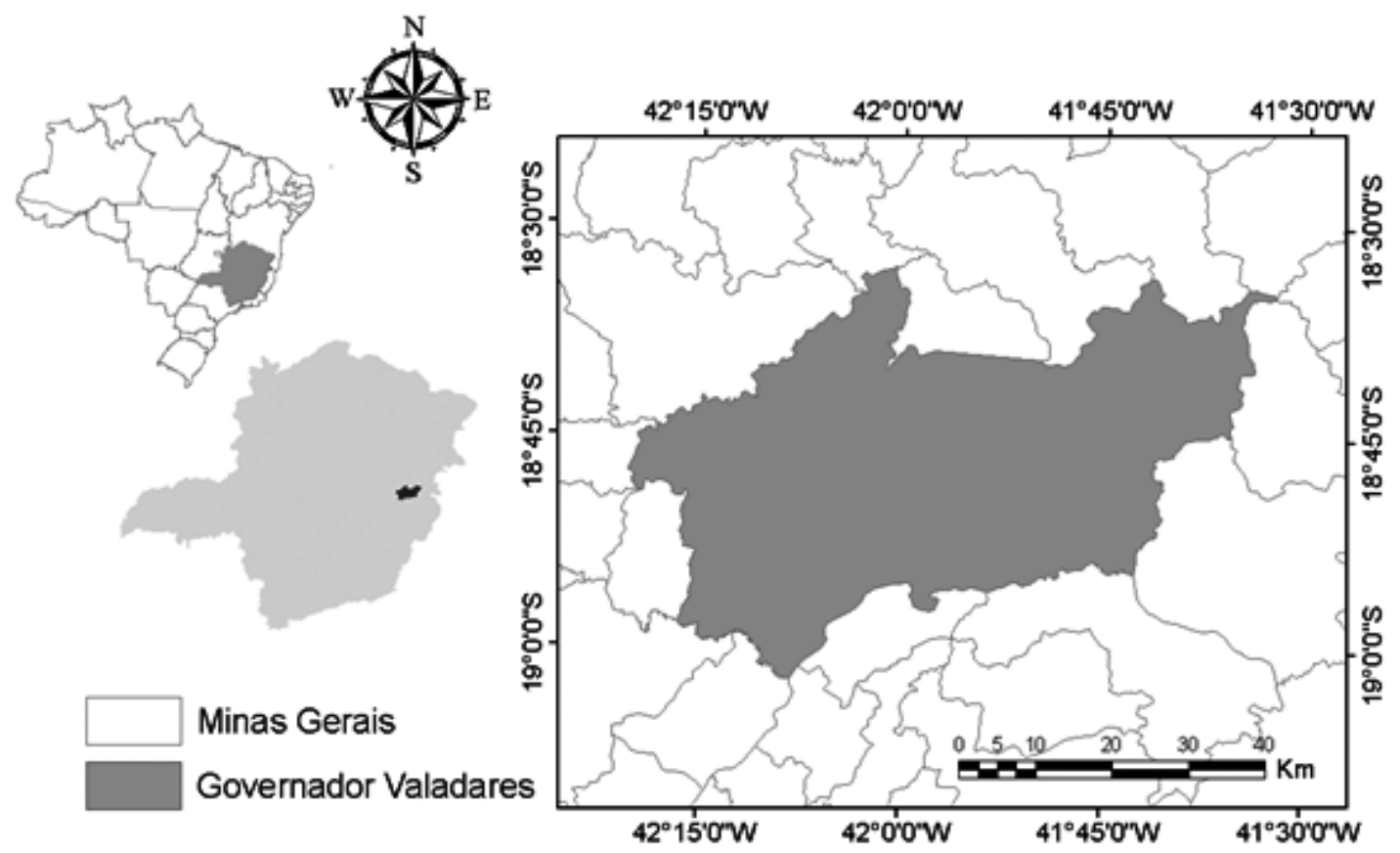

Figure 1. Geographic coordinates of the studied situations $18^{\circ} 51^{\prime} \mathrm{S}$ and $41^{\circ} 56^{\prime} \mathrm{W}$.

Table 1. Soil physical characteristics of the studied situations in the depth $0-30 \mathrm{~cm}$.

\begin{tabular}{lcccc}
\hline & \multicolumn{4}{c}{ Physical characteristics ${ }^{(1)}$} \\
\cline { 2 - 5 } Studied situations & Coarse sand & Fine sand & Silt & Clay \\
\cline { 2 - 5 } & \multicolumn{5}{c}{$[\%]$} \\
\hline Silvopastoral & 44.66 & 19.68 & 20.88 & 14.79 \\
Sugarcane & 40.21 & 11.03 & 25.2 & 23.56 \\
Pasture & 43.68 & 4.67 & 16.65 & 35.00 \\
Secondary forest & 22.83 & 17.80 & 31.87 & 28.00 \\
\hline
\end{tabular}

(1) Embrapa (1997).

Table 2. Soil chemical characteristics of the studied situations in the depth 0-30 cm.

\begin{tabular}{|c|c|c|c|c|c|c|c|c|c|c|}
\hline \multirow{3}{*}{ Studied situations } & \multicolumn{10}{|c|}{ Chemical characteristics ${ }^{(1)}$} \\
\hline & $\mathrm{P}$ & $\mathrm{K}^{+}$ & $\mathrm{Ca}^{2+}$ & $\mathrm{Mg}^{2+}$ & $\mathrm{Al}^{3+}$ & $\mathrm{H}+\mathrm{Al}$ & $\mathrm{t}$ & $\mathrm{BS}$ & AS & P-rem \\
\hline & \multicolumn{2}{|c|}{$\left[\mathrm{mg} \mathrm{dm}^{-3}\right]$} & \multicolumn{5}{|c|}{$\left[\mathrm{cmol}_{\mathrm{c}} \mathrm{dm}^{-3}\right]$} & \multicolumn{2}{|c|}{$[\%]$} & {$\left[\mathrm{mg} \mathrm{L}^{-1}\right]$} \\
\hline Silvopastoral & 5.2 & 97.2 & 2.2 & 0.9 & 0 & 4.0 & 3.34 & 45.58 & 0 & 16 \\
\hline Sugarcane & 6.1 & 97.1 & 1.2 & 1.2 & 0 & 5.6 & 2.64 & 32.12 & 0 & 13 \\
\hline Pasture & 15.9 & 155.6 & 4.8 & 0.4 & 0 & 3.6 & 6.19 & 60.87 & 0 & 13 \\
\hline Secondary forest & 9 & 117.05 & 4.8 & 0.8 & 0 & 4.5 & 5.89 & 56.73 & 0 & 11 \\
\hline
\end{tabular}

${ }^{(1)} \mathrm{P}, \mathrm{K}^{+}, \mathrm{Ca}^{2+}, \mathrm{Mg}^{2+}, \mathrm{Al}^{3+}, \mathrm{H}+\mathrm{Al}, \mathrm{CEC}$ effective (t), Bases saturation (BS); Aluminum saturation (As) (Embrapa, 1997); $\mathrm{P}$ remaining (P-rem) (Alvarez V. et al., 2000). 
of Pennisetum purpureum. The previous use accomplished with Brachiaria brizantha pasture in extensive, the implantation of pasture was done with plowing, harrowing, liming and planting fertilizer. The pasture is irrigated and intensively used in plots systems. The secondary forest (SF) comprises secondary vegetation established for approximately 30 years with previous use of sugarcane planting in a conventional systems done by burning the crop.

Soil samples were collected in June 2010 at a depth of 0-10, 10-20 and 20-30 cm with five replicates. The attributes evaluated were: soil organic carbon (SOC) according to Yeomans \& Bremner (1988); bulk density $(B d)$ done by the volumetric ring method; $\mathrm{pH}$ in the water and in $\mathrm{KCl}$; after, delta $\mathrm{pH}$ was calculated (Embrapa, 1997). The $O C$-stock accumulated in each soil layer was calculated from the expression:

In:

$$
O C \text {-stock }=B d^{*} S O C^{*} \mathrm{PD} / 10
$$

OC-stock: Carbon stock in the layer studied $\left(\mathrm{Mg} \mathrm{ha}^{-1}\right)$ SOC: Soil organic carbon $\left(\mathrm{g} \mathrm{Kg}^{-1}\right)$

$B d$ : Bulk density $\left(\mathrm{Kg} \mathrm{dm}^{-3}\right)$

PD: Profile depth $(\mathrm{cm})$
The normal distribution of data was studied thru the Shapiro-Wilk test and homogeneity of variance thru the Bartlett test. Analysis of variance (ANOVA) $(P \leq 0.05)$ followed the randomized design being studied each depth separately: when significant, the means were compared thru the Turkey test $(P \leq$ 0.05 ) using the SoftwareSISVAR (Ferreira, 2000). The means and standard error were calculated from an average of five replicated in three depths (0-10 $\mathrm{cm}, 10-20 \mathrm{~cm}$ and $20-30 \mathrm{~cm}$ ). The bulk density was compared from the confidence interval of $95 \%$.

\section{Results and Discussion}

The means of $B d$ between the different studied situations ranged from 0.8 to $1.4 \mathrm{Kg} \mathrm{dm}^{-3}$ (Figure 2). The sites under silvopastoral system (SP), sugarcane (SC) and pasture (PT) didn`t present difference between each other when evaluated in surface and subsurface to $B d$.The site with secondaryforest (SF) presented the lowest values of $B d$ in which they ranged from 0.8 to $0.9 \mathrm{Kg} \mathrm{dm}^{-3}$. The results corroborate with research that studied the impact of pasture and sugarcane on bulk density (Centurion et al., 2007; Muller et al., 2004). The sites with greater intensity of use, in general, present highest
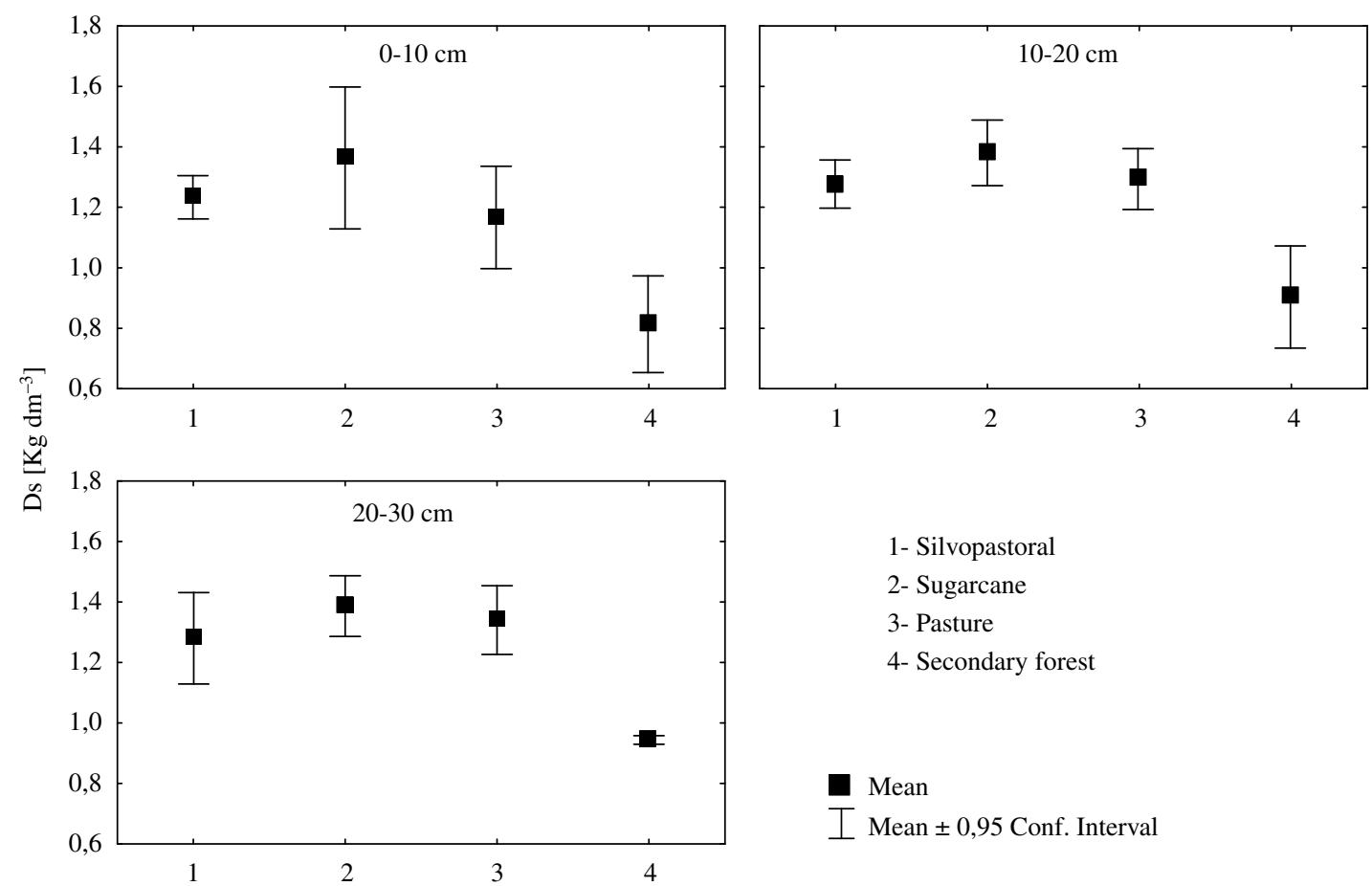

Figure 2. Bulk density (Bd) $\mathrm{Kg} \mathrm{dm}^{-3}$ of the studied situations. For the same depth means followed by the same bar indicate no significant difference between the studied situations, at the level of $95 \%$ for confidence interval. 
values of $B d$ (Aratani et al., 2009). The results of implantations of these intensely plowed areas, or excess animals in the areasof grassland.

Soil management with the preparations of agricultural machinery and animal tramplingon soil, brings the microaggregates and the particles dispersed unit closer by expulsing air and water, which keeps them apart, increasing the bulk density by reducing the total soil volume at a expense of reduced porosity. This result was reported by Fidalsk et al. (2009) in a study conducted in a Oxisol indicating the main cause of the $B d$ increase in the conventional systems, soil preparation with plowing.

Another aspect that can be mentioned is the increase of bulk density values are the highest sand content in the sites of PT, SP and SC when compared to SF site.

The PT site presented the highest value of $\mathrm{pH}$ in the surface and subsurface (Table 3), being the same for the sites of SF and SP in the depth of $0-10 \mathrm{~cm}$. The lowest value of these attribute were observed in the site with SC (Table 3). This result could have been influenced due to the increasing demand of nutrients from sugarcane mainly $\mathrm{Ca}^{2+}$, $\mathrm{Mg}^{2+}$ and $\mathrm{K}^{+}$and inadequate fertilization and liming. The largest export of these bases causes increase in the $\mathrm{H}^{+}$ion activity reducing $\mathrm{pH}$ in the soil. Oliveira et al. (2010) in his study found an average export of $188 \mathrm{Kg} \mathrm{ha}^{-1}$ of $\mathrm{K}^{+}, 187 \mathrm{Kg} \mathrm{ha}^{-1}$ of $\mathrm{Ca}^{2+}$ and 66
$\mathrm{Kg} \mathrm{ha}^{-1}$ of $\mathrm{Mg}^{2+}$ in cultivated areas with sugarcane irrigated under Ultisol. On the other hand, Braz et al. (2004) working with Brachiaria brizantha cv. Marandu and Panicum maximun cv. Mombaça in Ultisol found values of maximum export (evaluated the foliar limb up to 110 days) these grasses around $164 \mathrm{Kg} \mathrm{ha}^{-1}$ of $\mathrm{K}^{+}, 70 \mathrm{Kg} \mathrm{ha}^{-1}$ of $\mathrm{Ca}^{2+}$ and $40 \mathrm{Kg}$ $\mathrm{ha}^{-1}$ of $\mathrm{Mg}^{2+}$.

The delta $\mathrm{pH}$ values in general didn't differ between the studied situations (Table 3), except in the depth $0-10 \mathrm{~cm}$, where the site under SP system has lower values of this attribute, possibly the lowest clay content may have contributed this result (Table 1). The delta $\mathrm{pH}$ values indicate that the soil of the site in study presented negative charges, favoring the retention of cations and may favor the physical and chemical protection of soil organic matter.

Although the highest sand content in soil was observed in SC (Table 1), the highest average content of carbon $(S O C)$ was verified in that site, this effect was observed in all the depths being significantly superior to other systems in used in the surface area $0-10 \mathrm{~cm}$ (Table 3). The same happened to the SP system presented the highest sand content compared to the sites of SF and PT and presented highest content $S O C$ in comparison to these two systems. It was expected that soil with a clay-like texture to present the highest content of SOC. This positive relation was demonstrated for various Oxisol in

Table 3. pH, Delta pH, Soil organic carbon (SOC) and Organic carbon stock (OC-stock) of the studied situations.

\begin{tabular}{|c|c|c|c|c|c|}
\hline \multirow{2}{*}{ Dephts } & \multicolumn{4}{|c|}{ Studied situations } & \multirow{2}{*}{ C.V. $(\%)$} \\
\hline & Silvopastoral & Sugarcane & Pasture & Secondary forest & \\
\hline \multicolumn{6}{|c|}{$\mathrm{pH}$} \\
\hline 1 & $5.9 \pm 0.003 \mathrm{a}$ & $5.0 \pm 0.186 b$ & $6.1 \pm 0.096 \mathrm{a}$ & $5.8 \pm 0.065 \mathrm{a}$ & 3.07 \\
\hline 2 & $5.9 \pm 0.122 b$ & $5.1 \pm 0.020 \mathrm{c}$ & $6.3 \pm 0.066 \mathrm{a}$ & $5.5 \pm 0.118 b$ & \\
\hline 3 & $5.9 \pm 0.069 \mathrm{~b}$ & $5.5 \pm 0.155 b$ & $6.5 \pm 0.033 \mathrm{a}$ & $5.9 \pm 0.133 b$ & \\
\hline \multicolumn{6}{|c|}{ Delta pH } \\
\hline 1 & $-0.74 \pm 0.055 \mathrm{a}$ & $-0.67 \pm 0.056 \mathrm{ab}$ & $-0.55 \pm 0.095 \mathrm{ab}$ & $-0.43 \pm 0.015 \mathrm{ab}$ & 15.89 \\
\hline 2 & $-0.68 \pm 0.064 \mathrm{a}$ & $-0.67 \pm 0.020 \mathrm{a}$ & $-0.72 \pm 0.030 \mathrm{a}$ & $-0.49 \pm 0.067 \mathrm{a}$ & \\
\hline 3 & $-0.70 \pm 0.077 \mathrm{a}$ & $-0.65 \pm 0.044 \mathrm{a}$ & $-0.79 \pm 0.076 \mathrm{a}$ & $-0.60 \pm 0.049 \mathrm{a}$ & \\
\hline \multicolumn{6}{|c|}{ Soil organic carbon $\left[\mathrm{g} \mathrm{Kg}^{-1}\right]$} \\
\hline 1 & $6.90 \pm 0.031 \mathrm{ab}$ & $7.50 \pm 0.019 \mathrm{a}$ & $6.00 \pm 0.012 \mathrm{c}$ & $6.10 \pm 0.010 \mathrm{bc}$ & 5.22 \\
\hline 2 & $7.60 \pm 0.012 \mathrm{a}$ & $7.60 \pm 0.029 \mathrm{a}$ & $7.00 \pm 0.030 \mathrm{a}$ & $6.90 \pm 0.018 \mathrm{a}$ & \\
\hline 3 & $7.70 \pm 0.017 \mathrm{ab}$ & $8.00 \pm 0.027 \mathrm{a}$ & $7.40 \pm 0.011 \mathrm{ab}$ & $7.10 \pm 0.011 \mathrm{c}$ & \\
\hline \multicolumn{6}{|c|}{ Organic carbon stock $\left[\mathrm{Mg} \mathrm{ha}^{-1}\right]$} \\
\hline 1 & $8.54 \pm 0.476 b$ & $10.28 \pm 0.149 \mathrm{a}$ & $7.01 \pm 0.324 \mathrm{c}$ & $5.04 \pm 0.298 \mathrm{~d}$ & 6.06 \\
\hline 2 & $9.80 \pm 0.242 \mathrm{ab}$ & $10.44 \pm 0.274 \mathrm{a}$ & $9.07 \pm 0.028 b$ & $6.22 \pm 0.029 \mathrm{c}$ & \\
\hline 3 & $9.89 \pm 0.265 \mathrm{a}$ & $11.16 \pm 0.501 \mathrm{a}$ & $9.98 \pm 0.145 \mathrm{a}$ & $6.70 \pm 0.124 b$ & \\
\hline
\end{tabular}

* For the same depth, different letters indicate a significant difference between the studied situations, at the level of 5\%, after the Tukey's test. \pm The standard deviation. Depth 1: 0-10 cm; 2: 10-20 cm; 3: 20-30 cm. C.V. (\%): Coefficient of variation. 
the Northwest region of the state of Minas Gerais (Zinn et al., 2005) being observed similar results in different classes of soils in São Paulo (Luca et al., 2009). This influence is linked to the capacity of soil organic matter to form different types of bonds with particles of high specific surface, such as clay and silt fractions favoring the colloidal protection (Silva \& Mendonça, 2007).

Possibly, the increase of consumption of straw facilitated by improving the conditions of macroporosity, aeration of sandy soils favored the activity of decomposing microfauna decreasing the $\mathrm{C} / \mathrm{N}$ ratio that is indicative of humification of organic soil matter, thus providing increased contents of SOC to the soil (Luca et al., 2009).

Furthermore, the site of SC was observed high productivity $\left(150 \mathrm{Mg} \mathrm{ha}^{-1}\right)$ provided an increased intake of plant residues. Given that the site with harvest sugarcane without fire promoted the return of soil of $24 \%$ of the total produced as straw (Trivelin et al., 1996), the input of straw can be reached, 36 $\mathrm{Mg} \mathrm{ha}^{-1}$ year, therefore contributing to the elevation of the content of SOC.

This aspect was verified in a study developed by Galdos et al. (2009) who observed in the harvested sugarcane area without fire the rising contents of soil carbon due to the higher amount of straw.

In the site of SP the input of organic matter provided by the Brachiaria brizantha pasture even under continuous pasture could have obtained similar results to those found by Franchini et al. (2011) in integrated livestock crop systems which was $9 \mathrm{Mg}$ $\mathrm{ha}^{-1}$ year and $8 \mathrm{Mg} \mathrm{ha}^{-1}$ year, respectively inputted by roots system and shoots of intercropping.

The high productivity of pastures in region of Governador Valadares was pointed out in a study developed by Alencar et al. (2009). These authors found an average production of shoots in the areas of Brachiaria brizantha $\mathrm{cv}$. Marandu up to $17 \mathrm{Mg}$ $\mathrm{ha}^{-1}$ year in pastures well-established and managed. This indicates the potential of pastures in this region to input organic matter to the soil, being that this potential can increase when this system interplant with other cultures as noted in the SP systems.

Moreover, the secondary forest or native the amount of litter inputted by the soil can be higher than $10 \mathrm{Mg} \mathrm{ha}^{-1}$ year (Vital et al., 2004), therefore the SF in the present study due to passing through a natural regeneration still has low litterfall (visually observed).
Contents of $S O C$ at $10-20 \mathrm{~cm}$ depth in all studied situations showed similar behavior with contents ranging from $7.60 \mathrm{~g} \mathrm{Kg}^{-1}$ to $6.90 \mathrm{~g} \mathrm{Kg}^{-1}$, no statistical difference was observed. In the depth of 20-30 cm the site of reference SF was the one with the lowest values of this attribute. Higher values of SOC found in the sites CN, SP and PT when compared to the reference site at a depth of $20-40 \mathrm{~cm}$ can be due to the plowing and harrowing in those sites were previously deploying of current culture in which incorporated organic matter found in the surface therefore increase the content of $C$ in depth (Mendonça \& Rowell, 1994).

Among the situations studied, the one that showed the greatest potential of $O C$-stock was the $\mathrm{CN}$ site in both surface and subsurface (Table 3 ). The lowest value of $O C$-stock was observed in the SF site, possibly due to the time of establishment of this area and management in which the soil was submitted previously to natural regeneration did not yet permit the increase of $O C$-stock in the soil.

The SP area showed results inferior to the $\mathrm{CN}$ site when evaluated the $O C$-stock (Table 3), therefore higher to the sites of PT and SF in the layer of $0-10 \mathrm{~cm}$. In the layers $10-20 \mathrm{~cm}$ and 20-30 cm the SP and PT areas were statistically equal presenting values of $O C$-stock intermediate to the $\mathrm{CN}$ and SFsites.

The pastures sites may have presented a greater accumulation of $C$ increase the $O C$-stock in the soil (Chan et al., 2010). This factor is influenced by the type of management in which the pasture is submitted. When the under silvopastoral systems this stock can be similar to the forest areas (Neves et al., 2004). In the present study the results shows the sites under PT and SP favored the stock higher than the SF.

Although the results of this present study have showed that the SP and PT sites favored the increase of $O C$-stock than the reference SF, studies found in the literature are often contradictory. Most of these studies show that the major input of organic matter provided by the roots, the soil with pasture areas present similar or higher contents to those found in the forest environments (Tarré et al., 2001), while others showed values higher than the forest soils (Noordwijk et al., 1997), provided by the largest global input of organic matter. 


\section{$0-10 \mathrm{~cm}$}

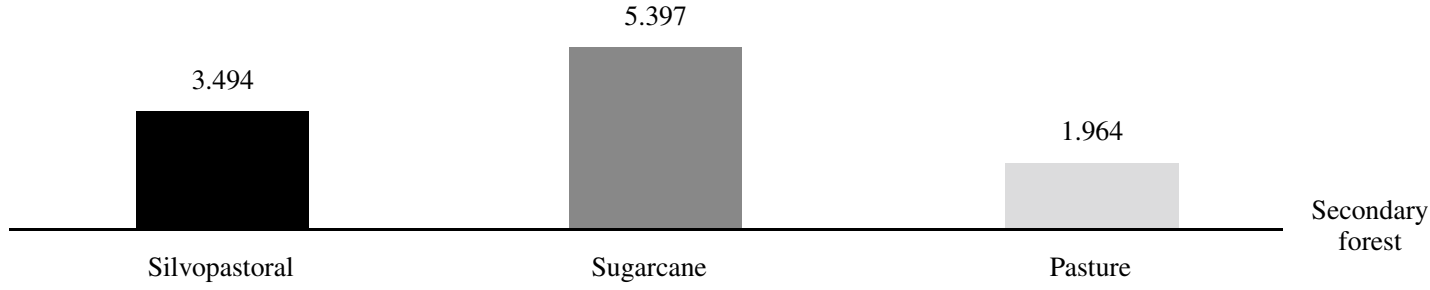

$10-20 \mathrm{~cm}$

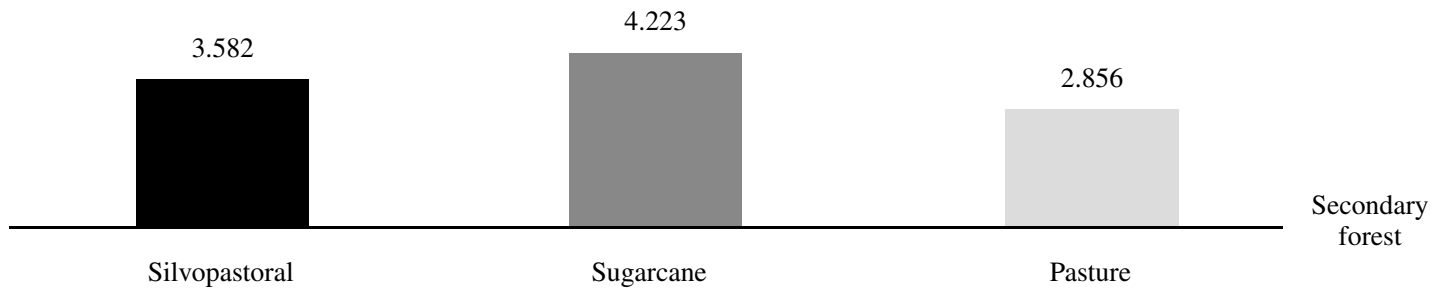

$20-30 \mathrm{~cm}$

4.457

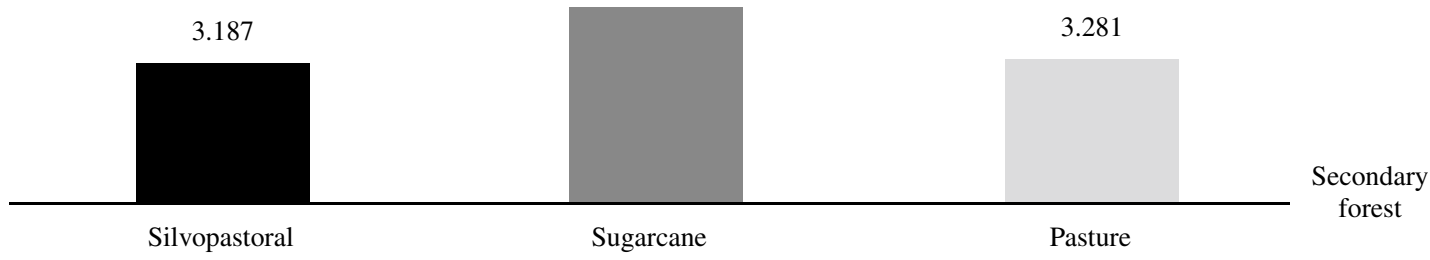

Figure 3. Soil organic carbon stock variation (OC-stock) $\mathrm{Mg} \mathrm{ha}^{-1}$ of the studied situations compared with Secondary forest (SF).

When evaluated the variation of $O C$-stock in function to reference site of SF, all systems promote increments of $C$ showing that the systems are efficient in increasing the $O C$-stock in soil and reducing the emissions of $\mathrm{C}-\mathrm{CO}_{2}$ (Figure 3). A special emphasis should be given to the $\mathrm{CN}$ sites in the depths of 0-10 $\mathrm{cm}$, which promoted an increase of 5,397 Mg ha ${ }^{-1}$, followed by SP (3,494 $\left.\mathrm{Mg} \mathrm{ha}^{-1}\right)$ and PT (1,964 $\left.\mathrm{Mg} \mathrm{ha}^{-1}\right)$.

These results allows to conclude that the management of fertilization and liming adopted and the no burning the sugarcane harvest has been effective in increasing the $O C$-stock of soil and that the SP systems in the surface layers $(0-10 \mathrm{~cm}$ and $10-20 \mathrm{~cm}$ ) are more efficient than continuous grazing system to raise the $O C$-stock.

\section{Conclusions}

1. The management of fertilization and harvesting of sugarcane (SC) in the region of Governador Valadaresis efficient to increase the $O C$-stock of soil.

2. The silvopastoral(SP) systems in the surface layers $(0-10 \mathrm{~cm}$ and $10-20 \mathrm{~cm})$ are more efficient increasing the $O C$-stock of soil when compared to the continuous grazing system (PT).

\section{Acknowledgement}

The authors thank the CAPES - Coordenação de Aperfeiçoamento de Pessoal de Nível Superior and the FAPEMIG - Fundação de Pesquisa do estado de Minas Gerais. 


\section{Literature Cited}

Alencar, C.A.B. de; Cóser, A.C.; Oliveira, R.A.; Martins, C.E.; Cunha, F.F. da; Fiqueredo, J.L.A.

2009. Produção de seis gramíneas manejadas por corte sob efeito de diferentes laminas de irrigação e estações anuais. Ciência e Agrotecnologia, 33: 1307-1313.

Alvarez, V.V.H.; Novais, R.F.; Dias, L.E.; Oliveira, J.A.

2000. Determinação e uso do fósforo remanescente. Boletim Informativo - Sociedade Brasileira de Ciência do Solo, 52: 27-32.

Aratani, R.G.; Freddi, O. da S.; Centurion, J.F.; Andrioli, I. 2009. Qualidade física de um Latossolo Vermelho Acriferrico sob diferentes sistemas de uso e manejo. Revista Brasileira de Ciência do Solo, 33: 677-687.

Braz, A.J.B.P.; Silveira, P. da M.; Zimmermann, F.J.P. 2004. Acumulação de nutrientes em folhas de milheto e dos capins braquiaria e monbaça. Pesquisa Agropecuária Tropical, 34: 83-87.

Centurion, J.F.; Freddi, O.S. da; Aratani, R.G.; Metzner, A.F.M.;

Beutler, A.N.; Andrioli, I.

2007. Influencia do cultivo da cana-de-açúcar e da mineralogia da fração argila nas propriedades físicas de Latossolos Vermelhos. Revista Brasileira de Ciência do Solo, 31: 199-209.

Chan, K.Y.; McCoy, D.

2010. Soil carbon storage potential under perennial pastures in the mid-north coast of New South Wales. Austrália, Tropical Grasslands, 44: 184-191.

Dias-Filho, M.B.

2010. Degradação de pastagens: processos, causas e estratégias de recuperação. 3. ed. Belém: Embrapa Amazônia Oriental, Brasil. 190 pp.

Embrapa - Empresa Brasileira de Pesquisa Agropecuária. Centro Nacional de Pesquisa de Solos.

1997. Manual de métodos de análise de solos. 2. ed. Rio de Janeiro: Embrapa CNPS, Documentos 1, 212 pp.

Ferreira, D.F.

2000. Análises estatísticas por meio do SISVAR (Sistema par Análise de Variância) para Windows: versão 4.0. In: Reunião Anual da Região da Brasileira da Sociedade Internacional de Biometria, 45. São Carlos. Anais... São Carlos: UFSCar, pp. 255-258.

Fidalski, J.; Barbosa, G.M.C.; Auler, P.A.M.; Pavan, M.A.; Beraldo, J.M.G.

2009. Qualidade física do solo sob sistemas de preparo e cobertura morta em pomar de laranja. Pesquisa Agropecuária Brasileira, 44: 76-83.

Franchini, J.C.; Debiasi, H.; Wruck, F.J.; Skorupa, L.A.; Wink,

N.N.; Guisolphi, I.J.; Caumo, A.L.; Hatori, T.

2010. Integração lavoura-pecuária: alternativa para diversificação e redução do impacto ambiental do sistema produtivo no Vale do Rio Xingu. Londrina: Embrapa Soja 20 pp.

Galdos, M.V.; Cerri, C.C.; Cerri, C.E.P.

2009. Soil carbon stocks under burned and unburned sugarcane in Brazil. Geoderma, 153: 347-352.

Intergovernmental Panel on Climate Change-IPCC

2001. Climate change 2001: The scientific basis. Cambridge, Cambridge University Press, 881.
Luca, E.F. de; Feller, C.; Cerri, C.C.; Barthés, B.; Chaplot, V.; Campos, D.C.; Manechini, C.

2008. Avaliação de atributos físicos e estoques de carbono e nitrogênio em solos com queima e sem queima de canavial. Revista Brasileira de Ciência do Solo, 32: 789-800.

Macedo, I.C.; Seabra, J.E.A.; Silva, J.E.A.R.

2008. Gren house gases emissions in the production and use of ethanol from sugar cane in Brazil: Ther 2005/2006 averages and prediction for 2020, 2008. Biomass and Energy, 32: 582-595.

Mendonça, E.S.; Rowell, D.L.

1994 Dinâmica do Alumínio e de Diferentes FraçõesOrgânicas de Um Latossolo Argiloso Sob Cerrado e Soja. Revista Brasileira de Ciência do Solo, 18: 295-303.

Muller, M.M.L.; Guimarães, M.F.; Desjardins, J.; Mitja, D.

2004 The relationship between pasture degradation and soil properties in the Brazilian amazon: a case study. Agriculture, Ecosystems and Environment, 103: 279-288.

Neves, C.M.N.; Silva, M.L.N.; Curi, N.; Macedo, R.L.G.; Tokura, A.M.

2004 Estoque de carbono em sistemas agrossilvopastoril, pastagem e eucalipto sob cultivo convencional na região noroeste do estado de Minas. Ciência e Agrotecnologia, 28: 1038-1046.

Noordwijk, M.V.; Cerri, C.C.; Woomer, P.L.; Nugroho, K.; Bernoux, M.

1997. Soil carbon dynamics in the humid tropical forest zone. Geoderma, 79: 187-225.

Silva, I.R.; Mendonça, E. de S.

2007. Matéria Orgânica do Solo. In: Novais, R.F., Alvarez, V.H.V. Barros, N.F., Fontes, R.L., Cantarutti, R.B.; Neves, J.C.L. Fertilidade do solo, Viçosa: Sociedade Brasileira de Ciência do Solo, pp. 275-374.

Tarré, R.; Macedo, R.; Cantarutti, R.B.; Rezende, C.P.; Pereira, J.M.; Ferreira, E.; Alves, B.J.R.;Urquiaga, S.; Boddey, R.M. 2001. The effect of the presence of a forage legume on nitrogen and carbon levels in soils under Brachiaria pastures in the Atlantic forest region of the South of Bahia, Brazil. Plant Soil, 234: 15-26.

Trivelin, P.C.O.; Rodrigues, J.C.S.; Victoria, R.L.

1996. Utilização por soqueira de cana-de-açúcar de início de safra do nitrogênio da aquamônia- ${ }^{15} \mathrm{~N}$ e uréia- ${ }^{15} \mathrm{~N}$ aplicado ao solo em complemento a vinhaça. Pesquisa Agropecuária Brasileira, 31: 89-99.

Vital, A.R.T.; Guerrini, I.A.; Franken, W.K.; Fonseca, R.C.B.

2004. Produção de serrapilheirae ciclagem de nutrientes de uma floresta estacional semidecidual em zona ripária. Revista Árvore, 28: 793-800.

Yeomans, J.C.; Bremner, J.M.

1988. A rapid and precise method for routine determination of organic carbon in soil. Communications in Soil Science and Plant Analysis, 19: 1467-1476.

Zinn, Y.L.; Lal, R.; Resck, D.V.S.

2005. Changes in soil organic carbon stocks under agriculture in Brazil. Soil \& Tillage Research, 84: 28-40. 